УдК 339.5:327

JEL classification F1, F13, K24, K33, O24

DOI: https://doi.org/10.35774/visnyk2021.02.066

\title{
Вікторія АДАМИК,
}

кандидат економічних наук, доцент

доцент кафедри менеджменту та міжнародного підприємництва

Національного університету «Львівська політехніка»

вул. Степана Бандери, 12, Львів, 79000, Україна

e-mail: viktoriia.v.adamyk@Ipnu.ua

ORCID ID: https://orcid.org/0000-0001-8842-8252

\section{Анастасія ПОРІЦЬКА,}

аспірант кафедри менеджменту та міжнародного підприємництва

Національного університету «Львівська політехніка»

вул. Степана Бандери, 12, Львів, 79000, Україна

e-mail: anastasiia.i.poritska@Ipnu.ua

ORCID ID: https://orcid.org/0000-0002-1086-8423

\section{МІЖНАРОДНІ ТА ВІТЧИЗНЯНІ ІНІЦІАТИВИ 3 РЕГУЛЮВАННЯ ЕЛЕКТРОННОЇ ТОРГІВЛІ}

Адамик В., Поріцька А. Міжнародні та вітчизняні ініціативи з регулювання електронної торгівлі. Вісник економіки. 2021. Вип. 2. C. 66-79. DOI: https://doi. org/10.35774/visnyk2021.02.066

Adamyk, V., Poritska, A. (2021). Mizhnarodni ta vitchyzniani initsiatyvy z rehuliuvannia elektronnoi torhivli. [International and domestic initiatives for e-commerce regulation]. Visnyk ekonomiky - Herald of Economics, 2, 66-79. DOI: https://doi.org/10.35774/ visnyk2021.02.066

\section{Анотація}

Вступ. Розвиток онлайн-торгівлі, що поступово витісняє традиційну, $\epsilon$ яскравим трендом глобальних економічних трансформацій. Ключові аспекти електронної торгівлі (укладення угод у мережі, приватність та захист споживачів, митне оформлення товаропотоків) потребують регулювання на міжнародному та національному законодавчому рівні.

Мета статmі полягає у дослідженні розвитку електронної торгівлі роздрібними товарами у XXI cm. у контексті оцінювання повноти та дієвості міжнародної та внутрішньої політики з регулювання інтернет-комерції, зокрема у ЄС та Україні.

Meтоди дослідження. Для дослідження правових аспектів регулювання електронної торгівлі використано загальнонаукові $і$ спеціальні методи, а

(C) Вікторія Адамик, Анастасія Поріцька, 2021. 
саме: аналіз і синтез, індукція й дедукція, абстрагування і конкретизація, опис, характеристика, узагальнення, порівняння. Методологічну базу для проведення дослідження становлять міжнародні нормативно-правові акти (Закони ООН, Директиви Європейського Союзу, Акти Міжнародних Організацій) та перелік Законів України щодо регулювання електронної сфрери.

Результати. Проведено аналізування показників розвитку електронної торгівлі на світовому ринку, вказано на їі стрімку динаміку. Розелянуто міжнародні ініціативи регулювання електронної торгівлі. Проведено порівняння аспектів нормативноправового регулювання електронної комерції в Україні та Європейському Союзі. Зроблено висновки щодо повноти та ступеня зрілості інституційної бази. Наголошено на необхідності посилення регуляторних механізмів у сфрері електронної комерції з метою створення сучасної інституційної системи, адаптованої до глобальної та європейської.

Перспективи. Майбутні дослідження важливо зосередити на розробці методичних рекомендацій з визначення ефективності імплементації ініціатив 3 регулювання інтернет-торгівлі на вітчизняному та глобальному рівнях.

Ключові слова: електронна (інтернет) торгівля, цифрровий бізнес, ініціативи з регулювання міжнародної електронної торгівлі, нормативно-правова база регулювання електронної торгівлі в Україні та ЄС.

Формули: 0, рис.: 2, табл.: 3, бібл.: 20.

\title{
Viktoriia ADAMYK,
}

PhD (Economics), Associate Professor Associate Professor of Department of

Management and International Entrepreneurship

National University "Lviv Polytechnic»,

st. Stepan Bandera St., 12, Lviv, 79000, Ukraine,

e-mail: viktoriia.v.adamyk@Ipnu.ua

ORCID ID: https://orcid.org/0000-0001-8842-8252

\section{Anastasiia PORITSKA,}

graduate student of Department of Management and International Entrepreneurship National University «Lviv Polytechnic»,

Stepan Bandera St., 12, Lviv, 79000, Ukraine,

e-mail: anastasiia.i.poritska@Ipnu.ua

ORCID ID: https://orcid.org/0000-0002-1086-8423

\section{INTERNATIONAL AND DOMESTIC E-COMMERCE REGULATION INITIATIVES}

\begin{abstract}
Introduction. The development of online commerce, which is gradually displacing the traditional one, is a clear trend of global economic transformations. Key aspects of e-commerce, such as online transactions, privacy and consumer protection, and customs clearance, need to be regulated at the international and national levels.
\end{abstract}


The purpose of the article is to study the development of e-commerce in retail goods in the XXI century. in the context of assessing the completeness and effectiveness of international and domestic

Research methods. General scientific and special methods were used to study the legal aspects of e-commerce regulation, namely: analysis and synthesis, induction and deduction, abstraction and concretization, description, characterization, generalization, comparison. The methodological basis for the study was international regulations (UN Laws, European Union Directives, Acts of International Organizations) and a list of laws of Ukraine on the regulation of the electronic sphere.

Results. The analysis of indicators of e-commerce development on the world market is carried out, its rapid dynamics is pointed out. International initiatives to regulate e-commerce are considered. A comparison of aspects of legal regulation of e-commerce in Ukraine and the European Union is carried out. Conclusions are made on the completeness and degree of maturity of the institutional base. Emphasis was placed on the need to strengthen regulatory mechanisms in the field of e-commerce in order to create a modern institutional system adapted to the global and European.

Perspectives. It is important to focus future research on the development of guidelines for determining the effectiveness of the implementation of initiatives to regulate e-commerce at the domestic and global levels.

Keywords: e-commerce, digital business, initiatives to regulate international e-commerce, regulatory framework for e-commerce regulation in Ukraine and the EU.

Formulas: 0 , fig .: 2, table: 3, bibl .: 20.

Постановка проблеми. На сьогодні для сучасного бізнесу характерне постійне збільшення можливостей постачальників, що призводить до посилення конкуренції і підвищення якості товарів та послуг. Змінюються способи організації та управління бізнесом, відбувається реінжиніринг (модернізація) бізнес-процесів і впровадження систем автоматизації. Комп'ютерні системи та мережі дедалі більше стають обов'язковим інструментом ділової комунікації та налагодження ланцюгів поставок. Зміни, викликані сучасними інформаційними технологіями, повністю відповідають основним характеристикам сучасного бізнес-середовища, основу якого становить електронна комерція й електронний ринок.

Протягом перших років виникнення Інтернет використовували як головний інструмент для державного та військового користування, а регулювання не вважали нагальною проблемою, оскільки доступ до мережі був обмеженим. Після відкриття Інтернетудля комерційної діяльності кіберпростір долучився до охопленої конфлліктами сфрери національної та міжнародної економічної політики. Питання регулювання електронної комерції було дискусійним, однак періодично загострювалося, коли у більшості країн світу простежувалась тенденція до дерегуляції ринків. Хоча багато лібералів розглядали Інтернет як новий засіб, який має бути вільний від державного регулювання, варто визнати, що поряд з можливостями Інтернету для комерції, творчості та спілкування, виникли нові можливості для зловживань, зокрема вторгнення в приватне життя та крадіжки, а також юридичні проблеми, пов'язані 3 контрактами, угодами та торгівлею. 
Аналіз останніх досліджень. Питання нормативно-правового регулювання електронної торгівлі є предметом наукових пошуків вітчизняних і зарубіжних науковців, зокрема Ю. Білявської, що досліджувала регулювання електронної комерції в Україні [1, с. 336-339], Л. Товкун та М. Федоровської, які вивчали питання правового регулювання електронної комерції на вітчизняному ринку [2, с. 282-286], Б. Бієрона та У. Ахмеда, які досліджували проблематику регулювання електронної комерції через призму міжнародної політики [3, с. 545-571]. Питання міжнародного регулювання електронної комерції вивчала О. Воробйова [4, с. 269-275]. Регулювання електронної комерції на світовому рівні аналізували О. Яценко, А. Грязіна, О. Шевчик, досліджуючи електронну комерцію як елемент глобальної торговельної системи [5, с. 4-15].

Мета статті полягає у дослідженні розвитку електронної торгівлі роздрібними товарами у XXI ст. у контексті оцінювання повноти та дієвості міжнародної та вітчизняної політики з регулювання інтернет-комерції.

Виклад основного матеріалу. За останні декілька років електронна комерція стала невід'ємною частиною світової системи роздрібної торгівлі. Як і багато інших галузей, роздрібна торгівля зазнала суттєвих змін після виникнення Інтернету, і завдяки цифровізації сучасного життя споживачі практично з усіх країн отримують прибуток від онлайн-транзакцій. Оскільки доступ до глобальної мережі стрімко зростає у всьому світі, кількість цифрових покупців постійно збільшується. У 2020 р. понад 2 млрд осіб придбали товари чи послуги в Інтернеті, а обсяг електронного роздрібного продажу перевищив 4,2 трлн дол. у всьому світі [6]. Стрімко зростають також відносні показники (рис. 1).

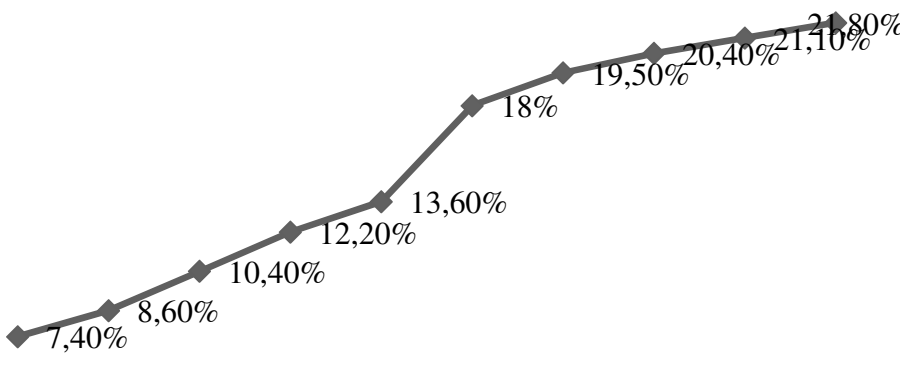

Рис. 1. Частка електронної комерції в загальній світовій роздрібній торгівлі з 2015 р. до 2024 р., \%

Джерело: розроблено авторами за [6].

У 2020 р. частка електронної торгівлі у загальному обсязі роздрібної торгівлі становила 18\% продажів у всьому світі. За дослідженням eMarketer, із загального обсягу роздрібних продажів у 2021 р. 19,5\% будуть надходити від покупок через Інтернет, тобто майже одна п'ята з кожного долару, витраченого на роздрібні товари цього року, буде здійснена через Інтернет [7]. Прогнозується, що цей показник 
досягне 21,8 \% у 2024 р. (6,388 трлн дол.). Таким чином, обсяги електронної комерції зростають щороку, що створює нові торговельні можливості у майбутньому (рис. 2).

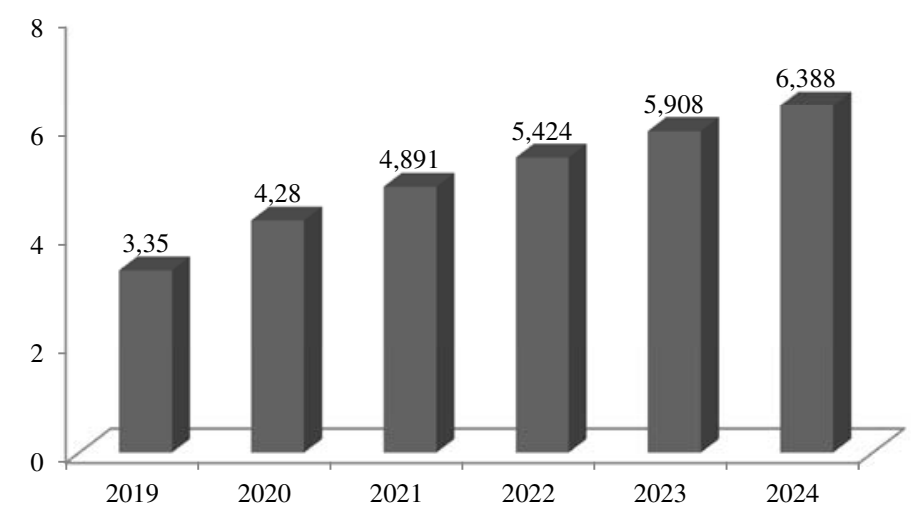

Рис. 2. Глобальний обсяг е-комерції у 2019-2020 рр. та прогнозовані значення на 2021-2024 рр., трлн дол.

Джерело: розроблено авторами за [7].

Частка покупців, що здійснюють онлайн-покупки за межами своєї країни, відображена у табл. 1.

Таблиця 1

Частка покупців, які здійснюють онлайн-покупки в зарубіжних інтернетмагазинах за регіонами

\begin{tabular}{|c|c|}
\hline Регіон & $\%$ \\
\hline Північна Америка & 45,5 \\
\hline Південна Америка & 54,6 \\
\hline Європа & 57,9 \\
\hline Африка & 55,5 \\
\hline Азіатсько-Тихоокеанський регіон & 63,4 \\
\hline
\end{tabular}

Джерело: розроблено авторами за [8].

Інтернет-покупки є однією з найбільш популярних онлайн-активностей у всьому світі. Покупці дедалі більше шукають товари в Інтернеті за межами своєї країни. В Європі понад 57\% онлайн-покупців підтвердили, що здійснювали покупки в іноземних інтернет-магазинах за останні півроку. Ця тенденція стає глобальною. Найбільша частка покупців, що здійснюють онлайн-покупки за кордоном, спостерігається в Азіатсько-Тихоокеанському регіоні і становить 64,4\%. Зазначимо, що внаслідок вибуху цифрового розвитку у цьому регіоні найбільш швидкозростаючим ринком Інтернетроздрібної торгівлі є Індонезія, а найбільшу частку ринку охоплює Китай. Розвиток цифрової роздрібної торгівлі в країнах цього регіону тісно пов'язаний із постійним покращенням доступу до Інтернету, особливо в межах спільнот, які тривалий час користувались повільним дешевим зв'язком через фрінансові або інфраструктурні обмеження. 
Розглянемо функціонування найбільших інтернет магазинів на світовому ринку (табл. 2).

Таблиця 2

Найбільш популярні вебмагазини роздрібної торгівлі у всьому світі в 2020 р. за середньомісячним трафіком

\begin{tabular}{|c|c|}
\hline Вебмагазин & $\begin{array}{c}\text { Середньомісячний трафік } \\
\text { (млн осіб) }\end{array}$ \\
\hline Amazon.com & 3676 \\
\hline eBay.com & 1012 \\
\hline Rakuten & 799 \\
\hline Apple.com & 429 \\
\hline Samsung.com & 603 \\
\hline AliExpress.com & 596 \\
\hline Walmart.com & 492 \\
\hline Etsy.com & 289 \\
\hline Ikea.com & 232 \\
\hline HomeDepot.com & 229 \\
\hline
\end{tabular}

Джерело: розроблено авторами за [6].

Інтернет-магазини роздрібної торгівлі значно збільшили трафік завдяки глобальній пандемії, оскільки значна частина населення залишається вдома і замовляє ті товари в Інтернеті, які до пандемії зазвичай купувала в магазині. Так, у середньому щомісячний трафрік Amazon.com становив майже 3,68 млрд відвідувачів у 2020 р., за ним слідує еВау.com (1,01 млрд відвідувань у середньому щомісяця). Amazon $€$ провідним інтернет-магазином у світі, чистий обсяг продажів якого становить 386 млрд дол. Більша частина доходу компанії генерується за рахунок онлайн-продажу електроніки та інших продуктів, послуг з підписки та діяльності AWS.

Лідером у структурі Amazon є платфрорма в США із показником 38\%, що становить близько 1,1 млн продавців, другу позицію посідає Великобританія з часткою 9,6\%, третю сходинку - Німеччина із показником 8,3\% [6].

Для продавців Amazon діє ряд нормативних документів щодо продажу товарів у кожній країні функціонування платформи [9]. Amazon виокремлює такі основні положення, які потрібно враховувати під час продажу продукції: податок та митниця; права інтелектуальної власності, зокрема обмеження законодавства про IB щодо паралельного ввезення товарів; експортний контроль; маркування та ярлики; екологія, здоров'я та безпека; відповідність продукції. На платформі представлений список країн з характеристикою правового забезпечення, що дає можливість продавцям здійснювати продаж безпечно та відповідно до законодавства. Так, наприклад, у США продавець надає податкову інформацію і сплачує податок з продажів. Якщо продавець імпортує продукцію до Європейського Союзу, його можуть зобов'язати сплатити 
ПДВ з моменту надходження товару в Європу, а також у країну призначення, куди він відвантажує товари. Знання основ правового регулювання електронної торгівлі необхідні для продавців, які повинні забезпечувати виконання законних вимог у процесі організації торгівлі.

Історія міжнародної політики з регулювання електронної комерції налічує понад 20 років. Незважаючи на відносно короткий проміжок часу, було прийнято багато міжнародно-правових актів, спрямованих на регулювання правовідносин у всесвітній мережі.

На міжнародному рівні електронну торгівлю регулює, насамперед, Комісія ООН з прав міжнародної торгівлі (ЮНСІТРАЛ), що розробила Закон «Про електронну комерцію» (1996 р.), який вказує на способи і методи вирішення правових проблем в електронній комерції. Інший Закон ЮНСІТРАЛ «Про електронні підписи» (2001р.) застосовується у тих випадках, коли електронні підписи використовуються у контексті торговельної діяльності [4, с. 271].

Міжнародна торговельна палата 3 регулювання ринку електронної торгівлі прийняла такі акти: загальні вимоги для посвідченої цифровим способом міжнародної комерції (1997); загальні принципи реклами і маркетингу в Інтернеті (1998 р).

Європейська економічна комісія ООН та Центр ООН сприяння торгівлі та електронного бізнесу ухвалили такі правові рішення:

- Типова угода обмінупідчас міжнародного комерційного використання електронного обміну даними (Додаток до Рекомендації № 26 «Комерційне використання угод обміну за електронного обміну даними», прийнята робочою групою зі сприяння міжнародним торговим процедурам Європейської економічної комісії ООН від 23.06.1995р.);

- Угода про електронну комерцію (Рекомендація № 31, ухвалена Центром ООН сприяння торгівлі та електронного бізнесу (UN/CEFACT), березень 2000 р., Женева) [4, с. 271].

Базовим нормативно-правовим актом, що регулює електронну комерцію в країнахчленах Європейського Союзу, є Директива 2000/31/ЄС Європейського парламенту та Ради «Про деякі правові аспекти інформаційних послуг, зокрема електронної комерції, на внутрішньому ринку» («Директива про електронну комерцію») від 08.06.2000 р. № 2000/31/€C [10], яка має регулювати визначені правові аспекти електронної комерції у ЄС. Імплементація Директиви спрямована на створення правової структури для забезпечення вільного переміщення інформаційних послуг між державами-членами. Європейський Союз прагне розвивати більш тісні зв'язки між державами та народами Європи з метою забезпечення економічного та соціального прогресу; внутрішній ринок охоплює зону без внутрішніх кордонів, у якій забезпечується вільний рух товарів, послуг та свобода організації; розвиток інформаційних послуг у межах зони без внутрішніх кордонів життєво важливий для скасування бар'єрів, які розділяють європейські народи.

У грудні 2020 р. Європейська Комісія подала до Європейського Парламенту та Європейської Ради пропозицію щодо створення єдиного ринку цифрових послуг (Закон про цифрові послуги DSA) та внесення змін до Директиви 2000/31/ЄС. Ця пропозиція і Закон про цифрові ринки (DMA) розроблені, щоб створити більш безпечний та більш відкритий цифровий простір для всіх користувачів та забезпечити рівні умови для бізнесу, адже спрямований на досягнення конкретних цілей, а саме: ефективного 
захисту споживачів та їхніх основних прав в Інтернеті; забезпечення фрункціонування системи прозорості та підзвітності для онлайн-платформ; сприяння інноваційному розвитку та конкурентоспроможності на єдиному ринку [11].

На сьогодні DSA - це законодавча ініціатива, правова реакція на сучасні виклики Інтернет-середовища, яку ще має схвалити Європейська Рада та Європейський Парламент, що, як очікується, займе близько півтора року, відколи Європейська Комісія запропонувала DSA у грудні 2020 р.

Зазначимо, що на сьогодні в Україні лише формується законодавча та нормативноправова база щодо регулювання сфрери Інтернет-послуг. Однією з інституцій, що забезпечує цю ділянку роботи, є Верховна Рада України.

Основні законодавчі акти, які вона ухвалила у сфері електронної комерції, такі:

Закон України «Про електронну комерцію» із змінами і доповненнями № 440-ІХ від 14.01.2020 (Відомості Верховної Ради (ВВР), 2015, № 45, ст. 410). Згідно з цим Законом визначено організаційно-правові засади діяльності у сфері електронної комерції в Україні, встановлено порядок вчинення електронних правочинів із застосуванням інформаційно-телекомунікаційних систем та визначено права і обов'язки учасників відносин у сорері електронної комерції [12].

Закон України «Про платіжні системи та переказ грошей в Україні» із змінами і доповненнями № 720-ІХ від 17.06.2020 14 (Відомості Верховної Ради України (ВВР), 2001, N 29, ст.137). Згідно з цим Законом визначено загальні засади функціонування платіжних систем і систем розрахунків в Україні, поняття та загальний порядок проведення переказу коштів у межах України, встановлено відповідальність суб'єктів переказу, а також окреслено загальний порядок здійснення нагляду (оверсайта) за платіжними системами [13].

Закон України «Про електронні документи та електронний документообіг» із змінами і доповненнями № 2155-VIII від 05.10.2017 (Відомості Верховної Ради України, 2003, № 36). Цей Закон встановлює основні організаційно-правові засади електронного документообігу та використання електронних документів [14].

Закон України «Про електронний цифровий підпис» із змінами і доповненнями № 1666-VIII від 06.10.2016 (Відомості Верховної Ради України, 2003, № 36). Згідно з цим Законом визначається правовий статус електронного цифрового підпису та регулюються відносини, що виникають у процесі використання електронного цифрового підпису [15].

Закон України «Про захист персональних даних» № 524-ІХ від 04.03.2020 (Відомості Верховної Ради України (ВВР), 2010, № 34, ст. 481). Цей Закон регулює правові відносини, пов'язані із захистом і обробкою персональних даних, та спрямований на захист основоположних прав і свобод людини й громадянина, зокрема права на невтручання в особисте життя у зв'язку з обробкою персональних даних [16].

Ще один орган, що виконує функції регулювання цифрового бізнесу на вітчизняному ринку, - це Міністерство цифрової трансформації України (створене у вересні 2019) - центральний орган виконавчої влади, який відповідає за формування та реалізацію державної політики у сфері цифровізації, відкритих даних, національних електронних інформаційних ресурсів, інтероперабельності - взаємодії мережевих систем у базі 
уніфікованих інтерфейсів або протоколів, впровадження електронних послуг та розвиток цифрової грамотності громадян [17].

Міністерство єцентральним засвідчувальним органом у сфері електроннихдовірчих послуг. Також до компетенції Міністерства належить розвиток широкосмугового доступу до мережі Інтернет, телекомунікаційних мереж та IT-індустрії.

Міністерство цифрової трансформації України забезпечує [17]:

- формування та реалізацію державної політики у сфері цифровізації, цифрової економіки, цифрових інновацій, електронного урядування та електронної демократії, розвитку інформаційного суспільства;

- розробку та реалізацію державної політики у сфері розвитку цифрових навичок та цифрових прав громадян;

- формування та реалізацію державної політики у сфері відкритих даних, розвитку національних електронних інформаційних ресурсів та інтероперабельності, розвитку інфраструктури широкосмугового доступу до Інтернету та телекомунікацій, електронної комерції та бізнесу;

- формування та реалізацію державної політики у сфері надання електронних та адміністративних послуг;

- розробку та реалізацію державної політики у сфері електронних довірчих послуг;

- формування та реалізацію державної політики у сфері розвитку IT-індустрії;

- виконання функцій центрального засвідчувального органу шляхом створення умов для функціонування суб'єктів правових відносин у сфері електронних довірчих послуг.

Порівняльний аналіз вітчизняних та європейських ініціатив з регулювання електронної комерції здійснено у табл. 3.

Таблиця 3

Аспекти та правові акти з регулювання електронної торгівлі в Україні та ЄС

\begin{tabular}{|c|c|c|}
\hline Аспекти & Україна & $\epsilon С$ \\
\hline Персональні дані & $\begin{array}{c}\text { Закон України «Про захист } \\
\text { персональних даних» }\end{array}$ & $\begin{array}{c}\text { Директива «Про захист осіб в сфері } \\
\text { переробки особистої інформації } \\
\text { та вільного переміщення такої } \\
\text { інформації» [18] }\end{array}$ \\
\hline Права покупців & $\begin{array}{c}\text { Даконектива України «Про електронну } \\
\text { комерцію» }\end{array}$ & $\begin{array}{c}\text { «Про захист прав споживачів щодо } \\
\text { дистанційних контр- } \\
\text { актів» [19] }\end{array}$ \\
\hline Права посередників & $\begin{array}{c}\text { Закон України «Про електронну } \\
\text { комерцію» }\end{array}$ & $\begin{array}{c}\text { Статті 12-15 Директиви про } \\
\text { електронну комерцію }\end{array}$ \\
\hline $\begin{array}{c}\text { Здійснення } \\
\text { розрахунків і } \\
\text { платежів }\end{array}$ & $\begin{array}{c}\text { Закон України «Про платіжні } \\
\text { системи та переказ грошей в } \\
\text { Україні» }\end{array}$ & $\begin{array}{c}\text { Директива «Про платіжні послуги» } \\
\text { [20] }\end{array}$ \\
\hline $\begin{array}{c}\text { Електронний } \\
\text { документообіг }\end{array}$ & $\begin{array}{c}\text { Закон України «Про електронні } \\
\text { документи та електронний } \\
\text { документообіг», Закон України } \\
\text { «ро електронний цифровий } \\
\text { підпис» }\end{array}$ & $\begin{array}{c}\text { статті 9-11 Директиви про } \\
\text { електронну комерцію }\end{array}$ \\
\hline
\end{tabular}

Джерело: розроблено авторами. 
Таким чином, у діяльності вітчизняних законодавчих та виконавчих органів частково відображена проблема електронної комерції, хоча загалом інституційна база з регулювання інтернет-торгівлі в Україні перебуває на етапі становлення і не має системного характеру. Особливу увагу потрібно звернути на питання безпекової складової та митного оформлення міжнародного електронного товарообігу.

Висновки. На основі проведеного дослідження можна зробити висновок, що електронна торгівля стрімко розвивається, витісняючи традиційну. Регулювання інтернет-торгівлі здійснюється як на міжнародному, так і на вітчизняному рівні, водночас нормативно-правова база змінюється, доповнюється новими джерелами та охоплює на сьогодні такі основні аспекти: персональні дані, права покупців, права посередників, здійснення розрахунків і платежів, електронний документообіг. Однак єдиного механізму контролювання та регулювання електронної торгівлі, що здійснюється як через великі міжнародні, так і через локальні інтернет-мережі, на глобальному рівні поки що не сформовано.

Перспективи подальших досліджень. Розробка методичних рекомендації з визначення ефективності регулювання електронної торгівлі, зокрема митного контролювання, на нашу думку, $€$ головним напрямком для проведення майбутніх досліджень.

\section{תimepamypa}

1. Білявська Ю. В. Регулювання електронної комерції в Україні. Молодий вчений. 2016. № 10. С. 336-339. URL: http://nbuv.gov.ua/ujrn/molv_2016_10_78

2. Товкун Л. В. Федоровська М. А. Актуальні питання правового регулювання електронної комерції в Україні. Юридичний науковий електронний журнал. 2020. № 9. C. 282-286. URL: http://www.lsej.org.ua/9_2020/71.pdf

3. Brian Bieron, Usman Ahmed. Regulating e-commerce through international policy: understanding the international trade law issues of e-commerce. Journal of worldtrade. 2012. Vol. 46, No. 3. P. 545-571.

4. Воробйова О. П. Нормативно-правове забезпечення електронної комерції: міжнародний досвід. Ефективність державного управління. 2012. № 30. С. 269-275. URL: http://nbuv.gov.ua/ujrn/efdu_2012_30_35

5. Яценко О. М., Грязіна А. С., Шевчик О. О. Електронна комерція як елемент глобальної торговельної системи. Актуальні проблеми економіки. 2019. № 8. C. 4-15. URL: https://eco-science.net/archive/2019/APE-08-2019/8.19_topic_ Yatsenko\%200.pdf

6. Statista - The Statistics Portal. Statista. URL: https://www.statista.com/

7. Data and Research on Digital. eMarketer. URL: https://www.emarketer.com

8. The Future of E-commerce: 10 Global E-commerce Trends. Convergine. URL: https://www.convergine.com/blog/the-future-of-e-commerce-10-global-ecommerce-trends/

9. Taxes and regulations with Amazon Global Selling - Amazon Seller Central. Amazon. URL: https://sellercentral.amazon.com/gp/help/external/G201468380 
10. Директива 2000/31/ЄС Європейського парламенту та Ради «Про деякі правові аспекти інформаційних послуг, зокрема, електронної комерції, на внутрішньому ринку» («Директива про електронну комерцію»): Директива Європейського Союзу від 08.06.2000 р. № 2000/31/€C. URL: https://zakon.rada.gov.ua/laws/ show/994_224

11. E-Commerce rules in the EU. Shaping Europe's digital future. URL: https://digitalstrategy.ec.europa.eu/en/policies/e-commerce-rules-eu

12. Про електронну комерцію : Закон України від 03.09.2015 p. № 675-VIII : станом на 19 квіт. 2020 р. URL: https://zakon.rada.gov.ua/laws/show/675-19

13. Про платіжні системи та переказ коштів в Україні : Закон України від 05.04.2001 p. № 2346-III : станом на 3 лип. 2020 p. URL: https://zakon.rada.gov. ua/laws/show/2346-14

14. Про електронні документи та електронний документообіг : Закон України від 22.05.2003 р. № 851-IV : станом на 7 листоп. 2018 p. URL: https://zakon.rada. gov.ua/laws/show/851-15

15. Про електронний цифровий підпис : Закон України від 22.05.2003 р. № 852-IV : станом на 7 листоп. 2018 p. URL: https://zakon.rada.gov.ua/laws/show/852-15

16. Про захист персональних даних : Закон України від 01.06.2010 p. № 2297-VI : станом на 23 квіт. 2021 p. URL: https://zakon.rada.gov.ua/laws/show/2297-17

17. Питання Міністерства цифрової трансформації: Постанова Кабінету Міністрів України від 18.09.2019 р. № 856 : станом на 12 лют. 2021 р. URL: https://zakon. rada.gov.ua/laws/show/856-2019-п

18. Директива 95/46/ЄС Європейського Парламенту і Ради «Про захист фізичних осіб при обробці персональних даних і про вільне переміщення таких даних» : Директива Європейського Союзу від 24.10.1995 р. № 95/46/ЄС : станом на 25 трав. 2018 p. URL: https://zakon.rada.gov.ua/laws/show/994_242

19. Директива $97 / 7 / € C$ Європейського парламенту та Ради «Про захист прав споживачів в дистанційних контрактах» : Директива Європейського Союзу від 20.05.1997 p. № 97/7/€C : станом на 23 верес. 2002 p. URL: https://zakon.rada. gov.ua/laws/show/994_245

20. Directive (EU) $2015 / 2366$ of the European Parliament and of the Council on payment services in the internal market, amending Directives 2002/65/EC, 2009/110/EC and 2013/36/EU and Regulation (EU) No 1093/2010, and repealing Directive 2007/64/ EC : Directive (EU) of 25.11.2015 № 2015/2366 : as of 23 December 2015. URL: https://eur-lex.europa.eu/eli/dir/2015/2366/oj/eng

\section{References}

1. Biliavska, Yu. V. (2016). Rehuliuvannia elektronnoi komertsii v Ukraini [Regulation of e-commerce in Ukraine]. Molodyi vchenyi [Young scientist], 10, 336-339. Retrieved from: http://nbuv.gov.ua/ujrn/molv_2016_10_78 [in Ukrainian]. 
2. Tovkun, L.V. Fedorovska, M.A. (2020). Aktualni pytannia pravovoho rehuliuvannia elektronnoi komertsi yi v Ukraini [Current issues of legal regulation of e-commerce in Ukraine]. lurydychnyi naukovyi elektronnyi zhurnal [Legal scientific electronic journal], 9, 282-286. Retrieved from: http://www.lsej.org.ua/9_2020/71.pdf [in Ukrainian].

3. Brian, Bieron, Usman, Ahmed (2012). Regulating e-commerce through international policy: understanding the international trade law issues of e-commerce. Journal of worldtrade, 46(3), 545-571 [in English].

4. Vorobiova, O. P. (2012). Normatyvno-pravove zabezpechennia elektronnoi komertsii: mizhnarodnyi dosvid [Regulatory and legal support of e-commerce: international experience]. Efektyvnist derzhavnoho upravlinnia [Efficiency of public administration], 30, 269-275. Retrieved from: http://nbuv.gov.ua/ujrn/ efdu_2012_30_35 [in Ukrainian].

5. Yatsenko, O. M., Hriazina, A. S., Shevchyk, O. O. (2019). Elektronna komertsiia yak element hlobalnoi torhovelnoi systemy [E-commerce as an element of the global trading system]. Aktualni problemy ekonomiky [Current economic problems] 8, 4-15. Retrieved from: https://eco-science.net/archive/2019/APE-08-2019/8.19_ topic_Yatsenko\%200.pdf [in Ukrainian].

6. Statista - The Statistics Portal. Statista. Retrieved from: https://www.statista.com/ [in English].

7. Data and Research on Digital. eMarketer. Retrieved from: https://www.emarketer. com [in English].

8. The Future of E-commerce: 10 Global E-commerce Trends. Convergine. Retrieved from: https://www.convergine.com/blog/the-future-of-e-commerce-10-global-ecommerce-trends/ [in English].

9. Taxes and regulations with Amazon Global Selling - Amazon Seller Central. Amazon. Retrieved from: https://sellercentral.amazon.com/gp/help/external/G201468380 [in English].

10. Dyrektyva 2000/31/YeS Yevropeiskoho parlamentu ta Rady «Pro deiaki pravovi aspekty informatsiinykh posluh, zokrema, elektronnoi komertsii, na vnutrishnomu rynku» («Dyrektyva pro elektronnu komertsiiu»): Dyrektyva Yevropeiskoho Soiuzu vid 08.06.2000 r. № 2000/31/YeS [Directive 2000/31 / EC of the European Parliament and of the Council on certain legal aspects of information services, in particular e-commerce, in the internal market (E-Commerce Directive): European Union Directive of 08.06.2000 № 2000 / 31 / EU]. Retrieved from: https://zakon. rada.gov.ua/laws/show/994_224 [in Ukrainian].

11. E-Commerce rules in the EU. Shaping Europe's digital future. Retrieved from: https://digital-strategy.ec.europa.eu/en/policies/e-commerce-rules-eu [in English].

12. Pro elektronnu komertsiiu : Zakon Ukrainy vid 03.09.2015 r. № 675-VIII : stanom na 19 kvit. 2020 r. [On e-commerce: Law of Ukraine of September 3, 2015 № 675- 
VIII: as of April 19. 2020]. Retrieved from: https://zakon.rada.gov.ua/laws/show/67519 [in Ukrainian].

13. Pro platizhni systemy ta perekaz koshtiv v Ukraini : Zakon Ukrainy vid 05.04.2001 r. № 2346-III : stanom na 3 lyp. 2020 r. [On payment systems and funds transfer in Ukraine: Law of Ukraine of April 5, 2001 № 2346-III: as of July 3. 2020]. Retrieved from: https://zakon.rada.gov.ua/laws/show/2346-14 [in Ukrainian].

14. Pro elektronni dokumenty ta elektronnyi dokumentoobih : Zakon Ukrainy vid 22.05.2003 r. № 851-IV : stanom na 7 lystop. 2018 r. [On electronic documents and electronic document circulation: Law of Ukraine of 22.05.2003 № 851-IV: as of November 7. 2018]. Retrieved from: https://zakon.rada.gov.ua/laws/show/85115 [in Ukrainian].

15. Pro elektronnyi tsyfrovyi pidpys : Zakon Ukrainy vid 22.05.2003 r. № 852-IV : stanom na 7 lystop. 2018 r. [On electronic digital signature: Law of Ukraine of May 22, 2003 № 852-IV: as of November 7. 2018]. Retrieved from: https://zakon.rada. gov.ua/laws/show/852-15 [in Ukrainian].

16. Pro zakhyst personalnykh danykh : Zakon Ukrainy vid 01.06.2010 r. № 2297VI : stanom na 23 kvit. 2021 r. [On personal data protection: Law of Ukraine of 01.06.2010 № 2297-VI: as of April 23. 2021]. Retrieved from: https://zakon.rada. gov.ua/laws/show/2297-17 [in Ukrainian].

17. Pytannia Ministerstva tsyfrovoi transformatsii: Postanova Kabinetu Ministriv Ukrainy vid 18.09.2019 r. № 856 : stanom na 12 liut. 2021 r. [Issues of the Ministry of Digital Transformation: Resolution of the Cabinet of Ministers of Ukraine of September 18, 2019 № 856: as of February 12. 2021]. Retrieved from: https://zakon.rada.gov.ua/ laws/show/856-2019-п [in Ukrainian].

18. Dyrektyva 95/46/YeS Yevropeiskoho Parlamentu i Rady «Pro zakhyst fizychnykh osib pry obrobtsi personalnykh danykh i pro vilne peremishchennia takykh danykh» : Dyrektyva Yevropeiskoho Soiuzu vid 24.10.1995 r. № 95/46/YeS : stanom na 25 trav. 2018 r. [Directive 95/46 / EC of the European Parliament and of the Council on the protection of individuals with regard to the processing of personal data and on the free movement of such data: European Union Directive of 24.10.1995 № 95/46 / EC: as of 25 May. 2018]. Retrieved from: https://zakon.rada.gov.ua/laws/ show/994_242 [in Ukrainian].

19. Dyrektyva 97/7/YeS Yevropeiskoho parlamentu ta Rady «Pro zakhyst prav spozhyvachiv v dystantsiinykh kontraktakh» : Dyrektyva Yevropeiskoho Soiuzu vid 20.05.1997 r. № 97/7/YeS : stanom na 23 veres. 2002 r. [Directive 97/7 / EC of the European Parliament and of the Council on the protection of consumers r rights in distance contracts: Directive of the European Union of 20 May 1997 № 97/7 / EC: as of 23 September. 2002]. Retrieved from: https://zakon.rada.gov.ua/laws/ show/994_245 [in Ukrainian]. 
20. Directive (EU) $2015 / 2366$ of the European Parliament and of the Council on payment services in the internal market, amending Directives 2002/65/EC, 2009/110/EC and 2013/36/EU and Regulation (EU) No 1093/2010, and repealing Directive 2007/64/ EC : Directive (EU) of 25.11.2015 № 2015/2366 : as of 23 December 2015. Retrieved from: https://eur-lex.europa.eu/eli/dir/2015/2366/oj/eng [in English].

Статтю отримано 05 травня 2021 р.

Article received May 5, 2021 